Canadian

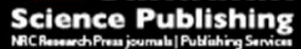

Canadian Journal of Forest Research Revue canadienne de recherche forestière

\title{
Macroanatomy and compartmentalization of recent fire scars in three North American conifers.
}

\begin{tabular}{|r|l|}
\hline Journal: & Canadian Journal of Forest Research \\
\hline Manuscript ID & cjfr-2015-0377.R1 \\
\hline Manuscript Type: & Article \\
\hline Date Submitted by the Author: & 23-Dec-2015 \\
\hline Complete List of Authors: & $\begin{array}{l}\text { Smith, Kevin; USDA Forest Service } \\
\text { Arbellay, Estelle; University of British Columbia, Forest and Conservation } \\
\text { Sciences } \\
\text { Falk, Donald A.; University of Arizona } \\
\text { Sutherland, Elaine; U.S. Forest Service }\end{array}$ \\
\hline Keyword: & fire injury, fire history, dendrochronology, wound pathology, barrier zone \\
\hline &
\end{tabular}

SCHOLARONE $^{\mathrm{m}}$
Manuscripts 
Canadian Journal of Forest Research, cjfr-2015-0377

Draft of Conifer fire scars by K.T. Smith and others

Page 1 of 27, 7 January 2016

1 Title: Macroanatomy and compartmentalization of recent fire scars in three North American

2 conifers.

4 Authors:

5 Kevin T. Smith, USDA Forest Service, Northern Research Station, Durham, NH, USA. Email:

6 ktsmith@fs.fed.us.

7 Estelle Arbellay, Department of Forest and Conservation Sciences, University of British

$8 \quad$ Columbia, Vancouver, Canada. Email: arbellay@mail.ubc.ca.

9 Donald A. Falk, School of Natural Resources and the Environment, University of Arizona, and

10 the Laboratory of Tree-Ring Research, University of Arizona, Tucson, AZ, USA.

11 Email:dafalk@email.arizona.edu.

12 Elaine Kennedy Sutherland, USDA Forest Service, Rocky Mountain Research Station,

13 Missoula, MT, USA. Email: esutherland@fs.fed.us.

14

15 Corresponding author: Kevin T. Smith, USDA Forest Service, 271 Mast Road, Durham, NH

16 03824, USA. Telephone: 603/868-7624, FAX: 603/868-7604, Email: ktsmith@fs.fed.us.

18 Running title: Conifer fire scars 
Canadian Journal of Forest Research, cjfr-2015-0377

Draft of Conifer fire scars by K.T. Smith and others

Page 2 of 27, 7 January 2016

19 Abstract: Fire scars are initiated by cambial necrosis caused by localized lethal heating of the

20 tree stem. Scars develop as part of the linked survival processes of compartmentalization and

21 wound closure. The position of scars within dated tree ring series is the basis for

22 dendrochronological reconstruction of fire history. Macroanatomical features were described for

23 western larch, ponderosa pine, and Douglas-fir injured by fire in 2003 and harvested in 2011 at

24 the Lolo National Forest near Missoula, Montana, USA. Bark scorch did not necessarily indicate

25 the formation of a scar. Wound-initiated discoloration inward from the scar face was bounded

26 tangentially by reaction zones. In western larch, the transition between earlywood and latewood

27 was much less abrupt in woundwood rings than in rings formed the same year but not associated

28 with a scar. Wood formed the year after injury contained tangential rows of resin ducts in the

29 earlywood. Compartmentalization plays a key role in resisting the spread of infection and the

30 loss of healthy sapwood and heartwood. Wound closure restores some degree of circumferential

31 continuity of the vascular cambium and reinforces stem structure. The terminology presented

32 here should facilitate communication among tree pathologists, wound anatomists, and

33 dendrochronologists. 
Canadian Journal of Forest Research, cjfr-2015-0377

Draft of Conifer fire scars by K.T. Smith and others

Page 3 of 27, 7 January 2016

Key words: fire injury, fire history, dendrochronology, wound pathology, reaction zone,

35 barrier zone, bluestain, conifer defense.

\section{Introduction}

The dendrochronological record of fire scars provides the primary evidence of the timing,

39 geographic extent, and other properties of forest fire regimes across scales of space and time

40 (Swetnam et al. 2009, Falk et al. 2011). Derived fire histories can then be related to observed or

41 reconstructed climatic patterns to infer predisposing environmental relationships associated with

42 periods of high or low fire frequency, size, and severity (Kitzberger et al. 2007, Swetnam and

43 Brown 2010, O’Connor et al. 2014, Rother and Grissino-Mayer 2014).

44 Dendroecological reconstruction of fire occurrence rests on the ability to date fire-related

45 injuries with high temporal $(<1 \mathrm{yr})$ precision. Fire scars provide such a high-resolution record,

46 typically for time scales of $10^{1}-10^{3} \mathrm{yr}$. However, not every tree exposed to fire forms a scar.

47 Once formed, scars can decay or be destroyed by subsequent mechanical damage over decades

48 and centuries. Thus, identifying additional anatomical markers of heat exposure would add to the

49 potential proxies for fire occurrence in the tree ring record (Arbellay et al. 2014a, 2014b).

50 This study describes active responses of compartmentalization and wound closure rather

51 than immediate or delayed mortality associated with lethal heating. Alternative mechanisms of

52 tree mortality from fire including the heat-induced cavitation of conducting xylem (Michaletz et

53 al. 2012), crown injury, and damage to fine root systems near the soil surface (Swezy and Agee

54 1991, Hood et al. 2007, 2010).

55 Trees killed outright by combustion or lethal heating do not produce fire scars. Far from

56 being passive "data loggers", surviving trees injured by fire undergo profound physiological 
Canadian Journal of Forest Research, cjfr-2015-0377

Draft of Conifer fire scars by K.T. Smith and others

Page 4 of 27, 7 January 2016

57 shifts from primary to stress metabolism (Smith 2015). The physiological and associated

58 anatomical responses to fire enable tree survival in ecosystems where fire is a recurring

59 disturbance process. These factors that confer individual tree survival provide the organismal

60 context for dendrochronology (Smith 2008) and reconstructions of fire history.

61 Localized lethality or necrosis of the vascular cambium results from the physical transfer of

62 heat greater than the tolerance threshold interaction of temperature and duration of exposure

63 (Johnson and Miyanishi 1995, Dickinson and Johnson 2004, Jones et al. 2006). After cambial

64 cell death, two dynamic processes result in scar formation: compartmentalization and wound

65 closure. Compartmentalization is the set of constitutive and induced anatomical and

66 physiological boundaries in wood and bark that resist the loss of normal function and the spread

67 of infection after physical injury (Shigo 1984, Shortle and Dudzik 2012). The decay resistance of

68 the fire scar record depends on effective compartmentalization. Wound closure is the reactive

69 formation of wood after injury that tends to grow over and attempt to close the wound surface

70 (termed "wound healing" in Fink 1999, and "wound closure" in Mattheck et al. 2015).

71 Successful wound closure reestablishes a continuous vascular cambium along the stem axis and

72 around the stem circumference.

73 Previous research on oak scars produced in response to prescribed fire described the loss of

74 normal function and development of wood decay within compartmentalization boundaries

75 (Smith and Sutherland 1999). The application of established terms and concepts from forest

76 pathology provided a framework to understand processes of fire scar formation in oak and

77 associated eastern broadleaved trees (Smith and Sutherland 2001).

78 In the intact stem of a mature North American conifer, a band of living sapwood surrounds a

79 core of nonliving heartwood (Wiedenhoeft 2013). The sapwood apoplast of cell walls and open 
Canadian Journal of Forest Research, cjfr-2015-0377

Draft of Conifer fire scars by K.T. Smith and others

Page 5 of 27, 7 January 2016

80 lumina conducts water and provides structural support (Kozlowski and Pallardy 1997). The

81 symplast of interconnected sapwood cytoplasm found in axial and radial parenchyma stores

82 starch as a local reserve stock of energy and biosynthetic feedstocks for primary and stress

83 metabolites (Kolosova and Bohlman 2012). As part of normal ageing and maturation, living

84 conifer sapwood is converted to non-living heartwood through consumption of locally stored

85 starch and biosynthesis of chemical protectants, tracheid aspiration accompanied by decreased

86 moisture content and ultimately, necrosis of the symplast (Kampe and Magel 2013).

87 Wounding and the xylem wound response interrupt the orderly transformation of sapwood

88 into heartwood. The most visible feature of this disruption is the wound-initiated transformation

89 of sapwood tangential to the wound into discolored wood. This discoloration of the former

90 sapwood reflects a series of processes performed by living sapwood cells to compartmentalize

91 the injury (Shigo and Hillis 1973, Shortle and Dudzik 2012). Although discolored wood in the

92 sapwood band may resemble heartwood in color, it lacks the comparatively greater decay

93 resistance of heartwood and is more vulnerable to the spread of infection. The discolored wood is

94 separated from sapwood by reaction zones, necrotic tissue enriched with waterproofing and

95 inhibitory extractives that resist the expansion of discolored wood into healthy sapwood present

96 at the time of wounding (Shain 1979, Schwarze et al. 2000). By definition, reaction zones are

97 formed through shifts in metabolism that deposit protective chemicals in sapwood present at the

98 time of injury (Shortle 1979). Plugging and aspiration of the tracheids isolate the discolored

99 wood from the hydraulic flow of normal sapwood. In the first annual ring formed after injury

100 there is frequently an anatomically distinct barrier zone that resists the outward spread of

101 infection towards the vascular cambium and into more recently formed sapwood (Shigo 1984,

102 Shortle and Dudzik 2012). 
Canadian Journal of Forest Research, cjfr-2015-0377

Draft of Conifer fire scars by K.T. Smith and others

Page 6 of 27, 7 January 2016

The objective of this paper is to describe and interpret compartmentalization and wound

104 closure processes in recent $(<10 \mathrm{yr}$ after wounding) fire scars of three common species of

105 Pinaceae from western North America: western larch (Larix occidentalis Nutt.), ponderosa pine

106 (Pinus ponderosa Lawson), and Douglas-fir (Pseudotsuga menziesii (Mirb.) Franco var. glauca

107 (Beissn.) Franco). Scars formed in these three species after a documented recent fire provides a

108 comparatively simple system to qualitatively investigate tree wound response. Dated fire scars of

109 both Pinus ponderosa and Pseudotsuga menziesii are widely used for fire history reconstruction

110 (Schweingruber 1993, Falk et al. 2011), whereas scars of Larix occidentalis has been used only

111 occasionally (Barrett et al. 1991, Marcoux et al. 2015). In this report, observations were centered

112 at the macroanatomical level, the visual scale most used by dendrochronologists to date fire

113 scars.

115 Methods

116 As part of a larger integrated study on the relationship of forest ecology to wildland fire in

117 western conifer forests of North America, we investigated the macroanatomy of fire scars in the

118 Dry Gulch $\left(46.51 .6^{\circ} \mathrm{N}, 114.14 .3^{\circ} \mathrm{W}\right)$ and Iris Point areas $\left(46.42 .437^{\circ} \mathrm{N}, 113.44 .054^{\circ} \mathrm{W}, 1800-\right.$

1191900 m.a.s.1) of the Lolo National Forest (LNF) near Missoula, Montana, USA. Sample trees

120 described here were injured in 2003 by the following fires in the LNF: Dry Gulch burned in the

121 Black Mountain fire (2-16 August 2003; 2961 ha in extent) and Iris Point burned in the Cooney

122 Ridge Complex fires (8 August to 15 October, 2003; 9600 ha in extent). At the time of sampling

123 in late August through September 2011, surviving trees with charred bark and occasionally

124 prominent fire scars were apparent (Fig. 1). 
Canadian Journal of Forest Research, cjfr-2015-0377

Draft of Conifer fire scars by K.T. Smith and others

Page 7 of 27, 7 January 2016

For the larger integrated study, we established the centers of circular plots at 50-m intervals

126 at each location. Up to three each of the nearest three living western larch, ponderosa pine, and

127 Douglas-fir trees $10-25 \mathrm{~cm}$ dbh with charred bark above the root flare were selected for sampling

128 and felled. We measured total tree height from the felled stem and cut 5-cm thick sample disks at

129 the root flare and at $25 \mathrm{~cm}, 50 \mathrm{~cm}, 75 \mathrm{~cm}, 1 \mathrm{~m}$, and then at $50-\mathrm{cm}$ increments along the stem to

$13050 \mathrm{~cm}$ above the top of the bark char. A total of 59 trees were sampled for the larger study. We

131 visually assessed the disks for patterns of compartmentalization and wound closure as identified

132 previously for oak (Smith and Sutherland 1999, 2001). We selected a subsample of 37 disks for

133 further macroanatomical investigation that represented the range of visible wound responses

134 (Table 1). Macroanatomical studies describe the anatomy and appearance of plant tissues under

135 relatively low magnification and reflected light. The level of visual detail is that of a dissecting

136 microscope (7-15x) or camera fitted with a macro lens. Macroanatomical investigations enable a

137 wider field of view with less intensive sample preparation than for histological analysis of

138 microtomed sections at the cost of reduced structural and histological detail.

139 The microanatomy of living xylem associated with fire scars from these collections at the

140 LNF includes the structural relationships of tracheids, rays, and resin ducts (Arbellay et al.

$1412014 a, 2014 b)$. In the current study, samples were sawn through the scar or necrotic cambium. In

142 addition to transverse stem sections, longitudinal sections through fire scars were also collected

143 and processed for macroanatomical comparison.

144 Sawn surfaces of sample disks and sections were smoothed with a graded series of

145 sandpaper through 600 grit mounted on a drill press. Sanded surfaces were polished with a fine

146 cotton sheet backed by a lambswool buffing pad also mounted on a drill press. Macro

147 photographs (components A-C in Figs 2-5) were taken with a Canon EOS 7D digital camera 
Canadian Journal of Forest Research, cjfr-2015-0377

Draft of Conifer fire scars by K.T. Smith and others

Page 8 of 27, 7 January 2016

148 fitted with a macro lens and mounted on a copy stand equipped with four daylight bulbs. To

149 produce a focused image across the field of view, vertical montages of photomicrographs

150 (component D in Figs 2-5) were constructed using the Leica Application Suite. Each montage

151 was flattened from about 10 images captured at successive focal planes using a Leica M165C

152 microscope fitted with a Leica DFC420 camera and with reflected fiber optic illumination.

153 Table 2 is a list of terms and concepts drawn from established terms from tree biology and

154 forest pathology (Shigo 1984, Fink 1999) and applied to the macroanatomy of fire scars. The

155 table is consistent with terms previously applied to the macroanatomy of fire scars in oak and

156 other hardwood species (Smith and Sutherland 2001). Signs of insect borers were evaluated

157 using the field guide of Hagle et al. (2003).

159 Results

160 General observations

161 At the 2011 sampling, prominent fire scars were identified by the robust rolls or ribs of

162 woundwood that tended to close over the exposed necrotic wood surface from the tangential and

163 axial margins of the wound (Fig. 1). Scars were attributed to the 2003 fire based on the position

164 of the wound in the annual ring series. For all three tree species, many scars from the 2003 fire

165 were still covered by adhering bark in 2011 and not readily apparent without tree dissection.

166 Beneath the adhering bark, woundwood partially or completely closed the wound face in all

167 three tree species. Frequently, but not uniformly, the rings of woundwood adjacent to and

168 growing over the wound surface were wider than rings along the same radius formed prior to

169 injury, and also wider than the same ring formed at a greater circumferential distance from the

170 wound margin. 
Canadian Journal of Forest Research, cjfr-2015-0377

Draft of Conifer fire scars by K.T. Smith and others

Page 9 of 27, 7 January 2016

Sapwood dieback and discolored wood extended beyond the arc and height of cambial

172 necrosis and the original injury, particularly in Douglas-fir and western larch. Due to the axial

173 orientation of xylem tracheids and to compartmentalization boundaries, discolored wood

174 occurred as a column, with tapered ends at the top and bottom. The discolored wood was

175 bounded tangentially by reaction zones and extended radially to the heartwood.

176 Woundwood rings narrowed abruptly with increasing tangential distance away from the

177 wound margin. Sample disks collected in 2011 frequently contained more than one region of

178 cambial scarring associated with the 2003 fire, resulting in a discontinuous or "patchy" necrosis

179 of the vascular cambium around the stem circumference. The periderm and phloem on the

180 woundwood ribs were thin and lacked a well-developed outer bark or rhytidome.

181 All three conifer species contained wood borer galleries in discolored wood with infrequent

182 incursions into heartwood. The galleries were packed with fine sawdust in an arced or fingerprint 183 tip print pattern.

\section{Western larch}

186 For each scar, a column of wound-initiated discolored wood extended radially across the

187 narrow sapwood band and inward to the heartwood (Fig. 2A, B). The tangential extent of the

188 discolored wood extended beyond the circumferential extent of the necrotic vascular cambium.

189 Two or more successive reaction zones were frequently formed at the sapwood / discolored

190 wood interface (Fig. 2B, C). Insect bore holes packed with sawdust occurred in discolored wood

191 but were absent from sapwood and heartwood. Heavy resin soaking was evident in tracheids to

192 the inside of the exposed wood surface. This resin soaking did not appear associated with resin

193 ducts (Fig. 2B, C). 
Canadian Journal of Forest Research, cjfr-2015-0377

Draft of Conifer fire scars by K.T. Smith and others

Page 10 of 27, 7 January 2016

Constitutive resin ducts were infrequent, usually occurring singly in latewood of rings

195 formed prior to fire injury. Cambial growth was complete in the fire-year ring in the sections we

examined. Tangential rows of numerous traumatic resin ducts occurred in the earlywood of the

1972004 growth ring, particularly in the woundwood and the transition between woundwood and

198 normal wood (Fig. 2B, D). Normal rings formed in 2003-2005 located away from the scar

199 contained an apparently abrupt shift between relatively thin-walled earlywood and thick-walled

200 latewood tracheids. At the transition between woundwood and normal wood, the earlywood to

201 latewood shift was less abrupt in the 2004 growth ring than in the 2003 and 2005 rings (Fig. 2D).

203 Ponderosa pine

204 Most scars of ponderosa pine were associated with bark furrows and concealed by attached

205 bark (Fig. 3A, B). In both exposed and concealed fire scars, ribs of woundwood tended to close

206 over the exposed wound surface. Ray formation in woundwood maintained a perpendicular

207 orientation to the vascular cambium and an oblique, curved angle to the previously formed wood

208 (Fig. 3B). Constitutive axial resin ducts contained thin-walled epithelial parenchyma and

209 frequently occurred in the latewood portion of annual rings (Fig. 3C). Traumatic resin ducts

210 appeared smaller and more frequent both in the earlywood and latewood in rings formed after

211 injury, extending beyond the arc of the exposed wood.

212 Two patterns of resin soaking frequently occurred: (1) a thin deposit immediately beneath

213 the killed wood surface (Fig. 3B), and (2) a wedge of discolored wood extending towards the

214 pith (Fig. 3A). The most prominent resin-soaking extended radially towards the pith from the

215 living phloem at the tangential edge of the wound. 
Canadian Journal of Forest Research, cjfr-2015-0377

Draft of Conifer fire scars by K.T. Smith and others

Page 11 of 27, 7 January 2016

Ray cells along the tangential edge of the wound and contiguous normal wood supported the

217 production of a pad of callus (Fig. 3D), identified by the jumbled arrangement of relatively thin-

218 walled, large, parenchyma cells that later extended into organized radial files of tracheids. The

219 position of the callus pad prior to the completion of the 2003 growth ring (Fig. 3D) indicated that

220 annual ring formation had not yet concluded at the time of the fire.

\section{Douglas-fir}

Fire killed the vascular cambium in both long and short arcs of the stem circumference (Fig.

224 4A). Discolored wood and bluestain infection frequently occurred between heartwood and the

225 necrotic vascular cambium (Fig. 4B). Decay and staining were extensive in the discolored wood

226 of Douglas-fir (Fig. 4B). Resin soaking was most apparent in wood formed prior to the fire and

227 near the tangential limits of the wound (Fig. 4B).

228 Rings of woundwood tended to partially or fully close over the fire scar. In some cases, the

229 vascular cambium of the woundwood ribs was killed, causing a new round of resin duct

230 formation and woundwood production and closure (Fig. 4C). Sparse, constitutive resin ducts

231 occurred in Douglas-fir latewood (Fig. 4D). Adjacent to the arc of killed vascular cambium,

232 radial files of relatively thick-walled latewood tracheids in the 2003 growth ring appeared to

233 terminate normally, indicating that cambial growth was complete before trees were injured. Early

234 in the 2004 ring, 3-5 apparently thin-walled and radially-flattened tracheids were produced (Fig.

235 4D). This anomaly is restricted to close proximity to the wound margin. A callus pad, probably

236 originating from sapwood rays, remained visible outside of the arc of necrotic vascular cambium

237 (Fig. 4D). In rings formed after injury and near the wound, traumatic resin ducts were produced 
Canadian Journal of Forest Research, cjfr-2015-0377

Draft of Conifer fire scars by K.T. Smith and others

Page 12 of 27, 7 January 2016

238 consistently in tangential rows in earlywood. Although resin-soaked, anatomically distinct resin

239 ducts were not observed within the callus pad.

240 The extent of woundwood production and wound closure in Douglas-fir was also evident in

241 longitudinal section. Frequently, wide woundwood rings produced a wide band of sapwood

242 following wound closure (Fig. 5A). Interior to the wound surface, discolored wood occupied the

243 radial width of tissues to the heartwood. The grain of the woundwood was wavy compared to the

244 straight grain of normal wood produced prior to fire injury (Fig. 5B). The woundwood was

245 protected by only a thin periderm and showed growth responses to additional injury or inclusions

246 during closure. Insect boreholes were restricted to discolored wood which had been sapwood at

247 the time of the 2003 fire (Fig. 5C). Most boreholes were tightly packed with fine wood-dust.

248 Narrow growth rings after injury resulted in a more narrow sapwood band in the uninjured face

249 of the stem. (Fig. 5D).

\section{Discussion}

252 Macroanatomical analysis helps to link large-scale environmental and landscape events such

253 as forest fire to the dynamic processes in living tissues that confer tree survival and that form the

254 tree-ring record. This biological linkage or organismal context (Smith 2008) of scars and related

255 wound responses is the basis of dendrochronological reconstructions of disturbance history.

256 This current research examined components of tree defense and survival in three species of

257 North American conifers that are regularly exposed to fire. Both open and closed fire scars were

258 frequently covered by adhering bark and not readily evident from simple observation of scorched

259 stems. The adhering bark would likely be sloughed off over time through weathering,

260 mechanical disturbance, or burned in a subsequent fire. For these recent scars from single fires, 
Canadian Journal of Forest Research, cjfr-2015-0377

Draft of Conifer fire scars by K.T. Smith and others

Page 13 of 27, 7 January 2016

261 the fire scar is visually defined in the intact stem both by the curved face of killed wood if

262 exposed and by the ribs of woundwood that tend to close over the exposed cambial necrosis and

263 wound surface. As with eastern oaks (Smith and Sutherland 1999), (1) the presence of scorched

264 bark did not necessarily indicate cambial necrosis and a fire scar, (2) open and closed fire scars

265 may be covered by adhering bark and not visible on the intact stem, and (3) the necrotic surface

266 of exposed fire scars was frequently but not consistently scorched. Consequently, the absence of

267 scorch on the exposed wood face did not exclude fire as the cause of injury.

268 Sapwood formed after injury in woundwood ribs and at greater distances away from the

269 wound margin appeared healthy with a light color and absence of bluestain infection. The

270 localization of discolored wood to rings present at the time of injury is consistent with the

271 compartmentalization concept (Shigo 1984, Shortle and Dudzik 2012).

272

\section{Compartmentalization}

274 Western larch produced the most visually distinct reaction zones of the three sampled

275 species, similar in appearance to reaction zones associated with recent fire scars in eastern oak

276 (Smith and Sutherland 1999). The two reaction zones on each tangential edge of discolored

277 wood in western larch indicated that the column of discolored wood had expanded from its initial

278 position and induced formation of a secondary reaction zone. Reaction zone formation does not

279 always successfully resist the spread of aggressive infections (Schwarze et al. 2000) and the zone

280 may be breached by boring insects (Shortle and Smith 1990). In a comparative analysis of host

281 response to wounding and infection in conifer and broadleaved species, Deflorio et al. (2009)

282 attributed the comparatively less pronounced reaction zones formed in Douglas-fir to a naturally

283 low frequency of radial and absent axial parenchyma. 
Canadian Journal of Forest Research, cjfr-2015-0377

Draft of Conifer fire scars by K.T. Smith and others

Page 14 of 27, 7 January 2016

The terms wound-initiated discoloration and discolored wood refer to former sapwood that

285 has responded to injury and infection, resulting in the loss or withdrawal of the symplast and

286 death of living sapwood cells (Shigo and Hillis 1973). Discolored wood associated with these

287 eight-year-old fire scars varied in radial depth or thickness, sometimes extending into the

288 heartwood. Due to the injury and death of living cells, the compartments of discolored wood do

289 not mature into heartwood normally present in these conifer species. Discolored wood

290 compartments may become surrounded by heartwood through the progressive maturation of

291 sapwood tangential to and to the outside of discolored wood (Shortle et al. 2010).

292 The alternative term "pathological heartwood" (Jorgenson 1962) for discolored wood is

293 misleading in that the wound-associated tissue does not have the functional characteristic of

294 enhanced decay resistance associated with heartwood nor the similar developmental origin from

295 ageing or maturation (Shigo and Hillis 1973). The alternative term "included sapwood" was

296 applied to injured sapwood that was spatially incorporated into the tree core as radial growth

297 continued, but without the preservative properties of heartwood (Bamber 1976, Fink 1999).

298 However, "included sapwood" is misleading as discolored wood has none of the properties of

299 cellular vitality, active water conduction, or the capacity for dynamic response to further injury.

301 Wound closure

302 The ribs of proliferating woody tissue at the margins of the scar that tend to close over the

303 exposed, killed wood surface are properly termed woundwood (Fink 1999). The misapplication

304 of the term callus for woundwood confuses two distinct tissues. Callus refers to a mass or pad of

305 thin-walled, undifferentiated, dividing cells containing relatively little lignin. Callus cells are

306 roughly isodiametric with each cell having equivalent lengths in all dimensions (Kozlowski and 
Canadian Journal of Forest Research, cjfr-2015-0377

Draft of Conifer fire scars by K.T. Smith and others

Page 15 of 27, 7 January 2016

307 Pallardy 1997). Callus associated with fire scars is initiated by dedifferentiation of vascular

308 cambial cells or sapwood parenchyma, usually associated with rays. The dedifferentiated cells

309 divide to form an undifferentiated callus mass. Physical pressure within the callus mass can

310 induce differentiation of a new vascular cambium (Fink 1999). Remnants of callus pads or

311 masses of roughly spherical and undifferentiated cells form at the wound margins and are visible

312 in some of the samples. In contrast, the ribs of woundwood produced by the vascular cambium

313 newly produced in callus or by the surviving vascular cambium at the wound margin contain

314 well-lignified, differentiated, thick-walled xylem cells normally incapable of division (Fink

315 1999).

316 The frequently wide rings of woundwood tend to hasten scar closure. Successful closure

317 reduces exposure of tissue to new infection and reduces the aeration and aerobic respiration of

318 established infections. Although the term "healing" will likely remain in use (Baker and Dugan

319 2013), wound closure is distinct from healing of animal systems in that functionality in injured

320 trees is restored by new tissue in new spatial positions (Shigo 1984) rather than by regeneration

321 in place. Even in the absence of complete wound closure and in the presence of a central void or

322 decay column, woundwood ribs reinforce stem structure and compensates for weakness or

323 "notch stress" at the scar (Mattheck 1998, Mattheck et al. 2015).

324 In the recent fire scars investigated here, the ring formed after fire injury contained a

325 tangential row of traumatic resin ducts in western larch and Douglas-fir that extended beyond the

326 edge of the cambial necrosis (Arbellay et al. 2014b). The vascular cambium beneath the thin

327 outer bark on the woundwood ribs was subject to further injury and subsequent closure

328 processes. Additional small injuries to the woundwood during closure resulted in similar

329 tangential bands of traumatic resin ducts, as was also reported for mechanical wounding of Larix 
Canadian Journal of Forest Research, cjfr-2015-0377

Draft of Conifer fire scars by K.T. Smith and others

Page 16 of 27, 7 January 2016

330 decidua (European larch) (Stoffel and Klinkmüller 2013). Our observations support the

331 conceptual model of fire-induced resin duct-related defense in western conifers developed by

332 Hood et al. (2015). The model describes the effect of fire suppression on increased mortality of

333 P. ponderosa by bark beetles. In brief, the model describes increased vulnerability to trees

334 through fire suppression and associated decreased investment in resin-based defenses. We

335 suggest that the stimulation of resin duct formation may also contribute to resistance of the

336 spread of infection. Further research is needed to determine whether this relationship can be

337 considered an example of systemic induced resistance (Eyles et al. 2010).

338 The borer tunnels observed were presumed to be produced by metallic wood borers (family

339 Buprestidae) due to the arced or whorled packing of degraded wood and frass (Hagle et al.

340 2003). Tunnels occurred in sapwood and discolored wood, with the discolored wood

341 occasionally occupying rings that would otherwise have been heartwood in the absence of injury.

342 Discolored wood in the position of the heartwood core may provide an additional resource for

343 borers intolerant of chemical protectants in heartwood.

344 We expect that bark thickness and texture would affect the extent of cambial necrosis

345 initiated by a given set of fire conditions. The degree of fire injury to the root system and to the

346 crown will affect the compartmentalization and closure of stem injury through effects on the

347 inter-related factors of tree vigor and stored energy resources.

348 The consistent application of terms to describe fire scars and wound-altered tissues should

349 facilitate communication within the fire history research community. Uniform terminology will

350 also expedite synthesis across disciplines including tree pathologists and entomologists

351 investigating tree survival and forest ecologists exploring the effect of environmental disturbance

352 on biological communities. Our work underscores the need to recognize that fire scar formation 
Canadian Journal of Forest Research, cjfr-2015-0377

Draft of Conifer fire scars by K.T. Smith and others

Page 17 of 27, 7 January 2016

353 is an adaptive process essential to tree survival and not just a passive epiphenomenon or

354 consequence of fire.

355 The tree physiological and anatomical responses documented here may provide the basis to

356 develop an additional potential proxy for tree exposure to fire, supplementing fire scars, tree

357 establishment dates, and other lines of evidence. As with currently available proxies, the

358 consistency and reliability of the anatomical record that responds to fire disturbance will require

359 rigorous quantitative statistical analysis. The convergence of multiple proxies into single

360 disturbance chronologies improves accuracy and reduces uncertainty in fire history

361 reconstruction (Margolis et al. 2007). Fire regimes of today's forests may be substantially

362 altered from their historical precedents, and so any additional evidence of past fire regimes prior

363 to Euro-American settlement will add to our understanding of this key ecosystem process.

\section{Acknowledgements}

366 We thank the Lolo National Forest, Missoula Ranger District for their cooperation in study

367 planning and sampling. We are grateful for the assistance of J. Farella, D. K. Wright, and I. Hyp

368 (all U.S. Forest Service Rocky Mountain Research Station) for sample collection and initial

369 processing. We especially thank K.R. Dudzik (U.S. Forest Service Northern Research Station)

370 for sample preparation and photography and to the Forest Health Protection unit at the Durham

371 NH Field Office of Northeastern Area State and Private Forestry for the use of the Leica

372 photosystem. 
Canadian Journal of Forest Research, cjfr-2015-0377

Draft of Conifer fire scars by K.T. Smith and others

Page 18 of 27, 7 January 2016

\section{References}

Arbellay, E., Stoffel, M., Sutherland, E.K., Smith, K.T., and Falk, D.A. 2014a. Changes in tracheid and ray traits in fire scars of North American conifers and their ecophysiological implications. Ann. Bot. 114: 223-232.

Arbellay, E., Stoffel, M., Sutherland, E.K., Smith, K.T., and Falk, D.A. 2014b. Resin duct size and density as ecophysiological traits in fire scars of Pseudotsuga menziesii and Larix occidentalis. Ann. Bot. 114: 973-980.

Baker, W.L., and Dugan, A.J. 2013. Fire-history implications of fire scarring. Can. J. For. Res. 43: 951-962.

Bamber, R.K. 1976. Heartwood, its function and formation. Wood Sci. Technol. 10: 1-8. Barrett, S.W., Arno, S.F., and Key, C.H. 1991. Fire regimes of western larch-lodgepole pine forests in Glacier National Park, Montana. Can. J. For. Res. 21: 1711-1720.

Deflorio, G., Franz, E., Fink, S., and Schwarze, F.W.M.R. 2009. Host responses in the xylem of trees after inoculation with six wood-decay fungi differing in invasiveness. Botany 87: 26-35. Dickinson, M.B., and Johnson, E.A. 2004. Temperature-dependent rate models of vascular cambium cell mortality. Can. J. For. Res. 34: 546-559.

Eyles, A., Bonello, P., Ganley, R., and Mohammed, C. 2010. Induced resistance to pests and pathogens in trees. New Phytol. 185: 893-908.

Falk, D.A., Heyerdahl, E.K., Brown, P.M., Farris, C., Fulé, P.Z., McKenzie, D., Swetnam, T.W., Taylor, A.H., and Van Horne, M.L. 2011. Multi-scale controls of historical forest-fire regimes: new insights from fire-scar networks. Front. Ecol. Environ. 9: 446-454. Fink, S. 1999. Pathological and regenerative plant anatomy. Gebruder Borntraeger, Berlin. 
Canadian Journal of Forest Research, cjfr-2015-0377

Draft of Conifer fire scars by K.T. Smith and others

Page 19 of 27, 7 January 2016

Hagle, S.K., Gibson, K.E., and Tunnock, S. 2003. A field guide to diseases \& insect pests of northern and central Rocky Mountain conifers. USDA For. Serv. Rep. R1-03-08. Available from http://www.fs.usda.gov/Internet/FSE_DOCUMENTS/stelprdb5188650.pdf [accessed 17 September 2015].

Hood, S.M., McHugh, C.W., Ryan, K.C., Reinhardt, E., and Smith, S.L. 2007. Evaluation of a post-fire tree mortality model for western USA conifers. Int. J. Wildland Fire 16: 679-689. Hood, S.M., Smith, S.L., and Cluck, D.R. 2010. Predicting mortality for five California conifers following wildfire. For. Ecol. Man. 260: 750-762.

Hood, S., Sala, A., Heyerdahl, E.K., and Boutin, M. 2015. Low severity fire increases tree defense against bark beetle attacks. Ecology 96: 1846-1855.

Johnson, E.A., and Miyanishi, K. 1995. The need for consideration of fire behavior and effects in prescribed burning. Restor. Ecol. 3: 271-278.

Jones, J.L., Webb, B.W., Buler, B.W., Dickinson, M.B., Jimenez, D., Reardon, J., and Bova, A.S. 2006. Prediction and measurement of thermally induced cambial tissue necrosis in tree stems. Int. J. Wildland Fire 15: 3-17.

Jorgenson, E. 1962. Observations on the formation of protection wood. For. Chron. 38: 292-294. Kampe, A., and Magel, E. 2013. New insights into heartwood and heartwood formation. In Cellular aspects of wood formation. Edited by J. Fromm. Springer-Verlag, Berlin. pp. 71-95. Kitzberger, T., Brown, P.M., Heyerdahl, E.K., Swetnam, T.W., and Veblen, T.T. 2007. Contingent Pacific-Atlantic Ocean influence on multicentury wildfire synchrony over western North America. Proc. Natl. Acad. Sci. 104: 543-548. 
Canadian Journal of Forest Research, cjfr-2015-0377

Draft of Conifer fire scars by K.T. Smith and others

Page 20 of 27, 7 January 2016

Kolosova, N., and Bohlman, J. 2012. Conifer defense against insects and fungal pathogens. In Growth and defense in plants. Edited by R. Matyssek, H. Schnyder, W. Oswald, D. Ernst, J.C. Munch, and H. Pretzsch. Springer-Verlag, Berlin. pp. 85-109.

Kozlowski, T.T., and Pallardy, S.G. 1997. Physiology of woody plants. $2^{\text {nd }}$ ed. Academic Press, San Diego, CA.

Marcoux, H.M., Gergel, S.E., Daniels, L.D., Da Silva, E., Gedalof, Z., and Hessburg, P.F. 2015. Differentiating mixed- and high-severity fire regimes in mixed-conifer forests of the Canadian Cordillera. For. Ecol. Man. 341: 45-58.

Margolis, E.Q., Swetnam, T.W., and Allen, C.D. 2007. A stand-replacing fire history in upper montane forests of the southern Rocky Mountains. Can. J. For. Res. 37: 2227-2241.

Mattheck, C. 1998. Design in nature. Springer-Verlag, Berlin.

Mattheck, C., Bethge, K., and Weber, K. 2015. The body language of trees: encyclopedia of visual tree assessment. Karlsruhe Institute of Technology, Karlsruhe.

Michaletz, S.T., Johnson, E.A., and Tyree, M.T. 2012. Moving beyond the cambium necrosis hypothesis of post-fire tree mortality: cavitation and deformation of xylem in forest fires. New Phytol. 194: 254-263.

O’Connor, C.D., Falk, D.A., Lynch, A.M., and Swetnam, T.W. 2014. Fire severity, size, and climate associations diverge from historical precedent along an ecological gradient in the Pinaleño Mountains, Arizona, USA. For. Ecol. Man. 329: 268-278.

Rother, M.T., and Grissino-Mayer, H.D. 2014. Climatic influences on fire regimes in ponderosa pine forests of the Zuni Mountains, NM, USA. For. Ecol. Man. 322: 69-77.

Schwarze, F.W.M.R., Engels, J., and Mattheck, C. 2000. Fungal strategies of wood decay in trees. Springer-Verlag, Berlin. 
Canadian Journal of Forest Research, cjfr-2015-0377

Draft of Conifer fire scars by K.T. Smith and others

Page 21 of 27, 7 January 2016

Schweingruber, F.H. 1993. Trees and wood in dendrochronology. Springer-Verlag, Berlin.

Shain, L. 1979. Dynamic responses of differentiated sapwood to injury and infection.

Phytopathol. 69: 1143-1147.

Shigo, A.L. 1984. Compartmentalization: a conceptual framework for understanding how trees grow and defend themselves. Ann. Rev. Phytopathol. 22: 189-214.

Shigo, A.L., and Hillis, W.E. 1973. Heartwood, discolored wood, and microorganisms in living trees. Ann. Rev. Phytopathol. 11: 197-222.

Shortle, W.C. 1979. Mechanisms of compartmentalization of decay in living trees. Phytopathol. 69: $1147-1151$.

Shortle, W.C., and Dudzik, K.R. 2012. Wood decay in living and dead trees: a pictorial overview. USDA For. Serv. Gen. Tech. Rep. NRS-97.

Shortle, W.C., and Smith, K.T. 1990. Decay column boundary layer formation in maple. In Biodeterioration research 3. Edited by G.C. Llewellyn, and C.E. O’Rear. Plenum Press, New York, NY. pp. 377-389.

Shortle, W.C., Dudzik, K.R., and Smith, K.T. 2010. Development of wood decay in woundinitiated discolored wood of eastern red cedar. Holzforschung 64: 529-536.

Smith, K.T. 2008. An organismal view of dendrochronology. Dendrochronologia 26: 185-193.

Smith, K.T. 2015. Compartmentalization, resource allocation, and wood quality. Curr. For. Rep. 1: $8-15$.

Smith, K.T., and Sutherland, E.K. 1999. Fire scar formation and compartmentalization in oak. Can. J. For. Res. 29: 166-171.

Smith, K.T., and Sutherland, E.K. 2001. Terminology and biology of fires scars in selected central hardwoods. Tree-Ring Res. 57: 141-147. 
Canadian Journal of Forest Research, cjfr-2015-0377

Draft of Conifer fire scars by K.T. Smith and others

Page 22 of 27, 7 January 2016

Stoffel, M., and Klinkmüller, M. 2013. 3-D analysis of anatomical reactions in conifers after mechanical wounding: first qualitative insights from X-ray computed tomography. Trees $\mathbf{2 7}$ : $1805-1811$.

Swetnam, T.W., and Brown, P.M. 2010. Climatic inferences from dendroecological reconstructions. In Dendroclimatology: developments in paleoenvironmental research 11. Edited by M.K. Hughes, T.W. Swetnam, and H.F. Diaz. Springer, Dordrecht. pp. 263-295.

Swetnam, T.W., Baisan, C.H., Caprio, A.C., Brown, P.M., Touchan, R., Anderson, R.S., and Hallett, D.J. 2009. Multi-millennial fire history of the Giant Forest, Sequoia National Park, California, USA. Fire Ecol. 5: 120-150.

Swezy, D.M., and Agee, J.K. 1991. Prescribed-fire effects on fine-root and tree mortality in oldgrowth ponderosa pine. Can. J. For. Res. 21: 626-634.

Wiedenhoeft, A. 2013. Structure and function of wood. In Handbook of wood chemistry and wood composites. Edited by R.B. Rowell. CRC Press, Boca Raton. pp. 9-32. 
Canadian Journal of Forest Research, cjfr-2015-0377

Draft of Conifer fire scars by K.T. Smith and others

Page 23 of 27, 7 January 2016

Table 1. Sample trees dissected for characterization of fire scars in transverse section at Lolo

National Forest, Montana, USA.

\begin{tabular}{llll}
\hline Species & Number of trees & Mean DBH (and range), $\mathrm{cm}$ & Number of stem disks
\end{tabular}

\begin{tabular}{llll} 
Larix occidentalis & 6 & $19(15-24)$ & 13 \\
Pinus ponderosa & 3 & $21(19-23)$ & 10 \\
Pseudotsuga menziesii & 6 & $16(12-23)$ & 14 \\
\hline
\end{tabular}


Canadian Journal of Forest Research, cjfr-2015-0377

Draft of Conifer fire scars by K.T. Smith and others

Page 24 of 27, 7 January 2016

Table 2. Glossary of preferred macroanatomical terms and their sources used to describe fire scars in Pinus ponderosa, Larix decidua, and Pseudotsuga menziesii.

\begin{tabular}{lll}
\hline Term & Characteristics & Sources $^{a}$
\end{tabular}

Barrier zone

A compartmentalization boundary of

Fink 1999

anatomically and chemically distinct xylem

Shigo 1984

formed after wounding.

Callus or Callus pad Mass of undifferentiated, roughly spherical,

Fink 1999

dividing cells forming at the wound margin

Shigo 1984

or from outgrowths of xylem rays.

Compartmentalization

After live sapwood is wounded,

Fink 1999

compartmentalization is the boundary-setting

Shigo 1984

process that resists the loss of function and

spread of infection. Compartmentalization

includes both constitutive and inducible

features of tree anatomy and physiology.

Discolored wood $\quad$ Former sapwood that has been infected by

Shigo and Hillis 1973

microorganisms introduced by wounding

and which no longer contains living tree

cells. Discolored wood is typically enclosed

by reaction zones in sapwood present at the

time of injury and by a barrier zone in wood 
Canadian Journal of Forest Research, cjfr-2015-0377

Draft of Conifer fire scars by K.T. Smith and others

Page 25 of 27, 7 January 2016

formed after injury.

Heartwood

Wood in the core of the living tree that

Shigo and Hillis 1973

through age or maturation lacks living tree

cells and that may contain wood extractives

that tend to confer decay resistance.

Reaction zone

A compartmentalization boundary formed by

Shain 1979

shifts in metabolism to produce protective

chemicals in wood present at the time of

wounding.

Sapwood

Wood that contains the living symplast

Shigo and Hillis 1973

involved in water conduction, stores starch

or other energy reserves, and dynamically

responds to injury and infection.

Woundwood

Wood produced at the margin of a wound,

Fink 1999

tending to close over the wound surface. $\quad$ Shigo 1984

\footnotetext{
${ }^{a}$ Sources are commonly available reference texts or articles that may not be the original source of the terms as used here.
} 
Canadian Journal of Forest Research, cjfr-2015-0377

Draft of Conifer fire scars by K.T. Smith and others

Page 26 of 27, 7 January 2016

\section{Figure captions}

Figure 1. Open fire scar on ponderosa pine in 2011, injured in the Black Mountain fire of 2003 at the study area in the Lolo National Forest of western Montana, USA.

Figure 2. Transverse stem section of western larch containing (A) closed (upper) and open (lower) fire scars and two detail areas (white boxes). (B) Detail from A (upper) with discolored wood (DW), an arc of necrotic vascular cambium (white arrows), heartwood (HW), sapwood (SW), reaction zones (numbered black arrows), resin soaking (triangle), beetle bore holes (open arrows), and detail area (white box). (C) Detail from A (lower right) with woundwood (ww) closing the necrotic wound face beneath killed, adhering bark (white stars). (D) Detail from B with a tangential row of resin ducts (arrows) in latewood formed the year after fire injury. In the image, the 2003 ring is located beneath the 2004 ring and cropped.

Figure 3. Transverse stem section through three fire scars of ponderosa pine containing (A) woundwood (WW), discolored wood (DW), reaction zones (open arrows), resin soaking (triangles) and three detail areas (white boxes). (B) Detail from A (left) with WW covering a remnant of killed phloem (open arrows) retained on the wound surface and killed, adhering bark (white stars). (C) Detail from A (center) with constitutive resin canals in latewood (arrows). (D) Detail from A (right) with a callus pad (CP) and traumatic resin ducts (black arrow).

Figure 4. Transverse stem section of Douglas-fir containing (A) a large open (upper half of section), a closed fire scar (lower left), and two detail areas (white boxes). (B) Detail from A 
Canadian Journal of Forest Research, cjfr-2015-0377

Draft of Conifer fire scars by K.T. Smith and others

Page 27 of 27, 7 January 2016

(right) with extensive discolored wood (DW), bluestain (BS), heartwood (HW), resin soaking (triangles), the edge of the necrotic vascular cambium (white arrow) and thin bark and narrow phloem (open arrow). (C) Detail from A (left) with the arc of necrotic cambium (between the white arrows), woundwood (WW) and necrotic cambium associated with a later injury (black arrows), and a detail area (white box). (D) Detail from $\mathrm{C}$ with isolated constitutive resin ducts (black arrows), a callus pad (CP), radially-flattened tracheids and successive tangential rows of traumatic resin ducts occur in the 2006 and 2008 growth rings (open black arrows).

Figure 5. Longitudinal stem section through a fire scar of Douglas-fir. (A) Resin soaking (triangles) above the lower limit of killed vascular cambium (white arrow), discolored wood (DW), and heartwood (HW), and three detail areas (white boxes). (B) Detail from A (center left) with adhering killed bark (stars) located to the outside of new phloem and thin periderm (collectively labelled P). Sapwood (SW) frequently contained wavy grain and occasional inclusions (arrow). (C) Detail from A (lower left), with a barrier zone (arrows) and beetle bore holes in DW. (D) Detail from the uninjured face of A (right), showing the narrow band of healthy SW to the outside of heartwood (HW) as well as thick phloem (\#), and the welldeveloped outer bark (white stars). 


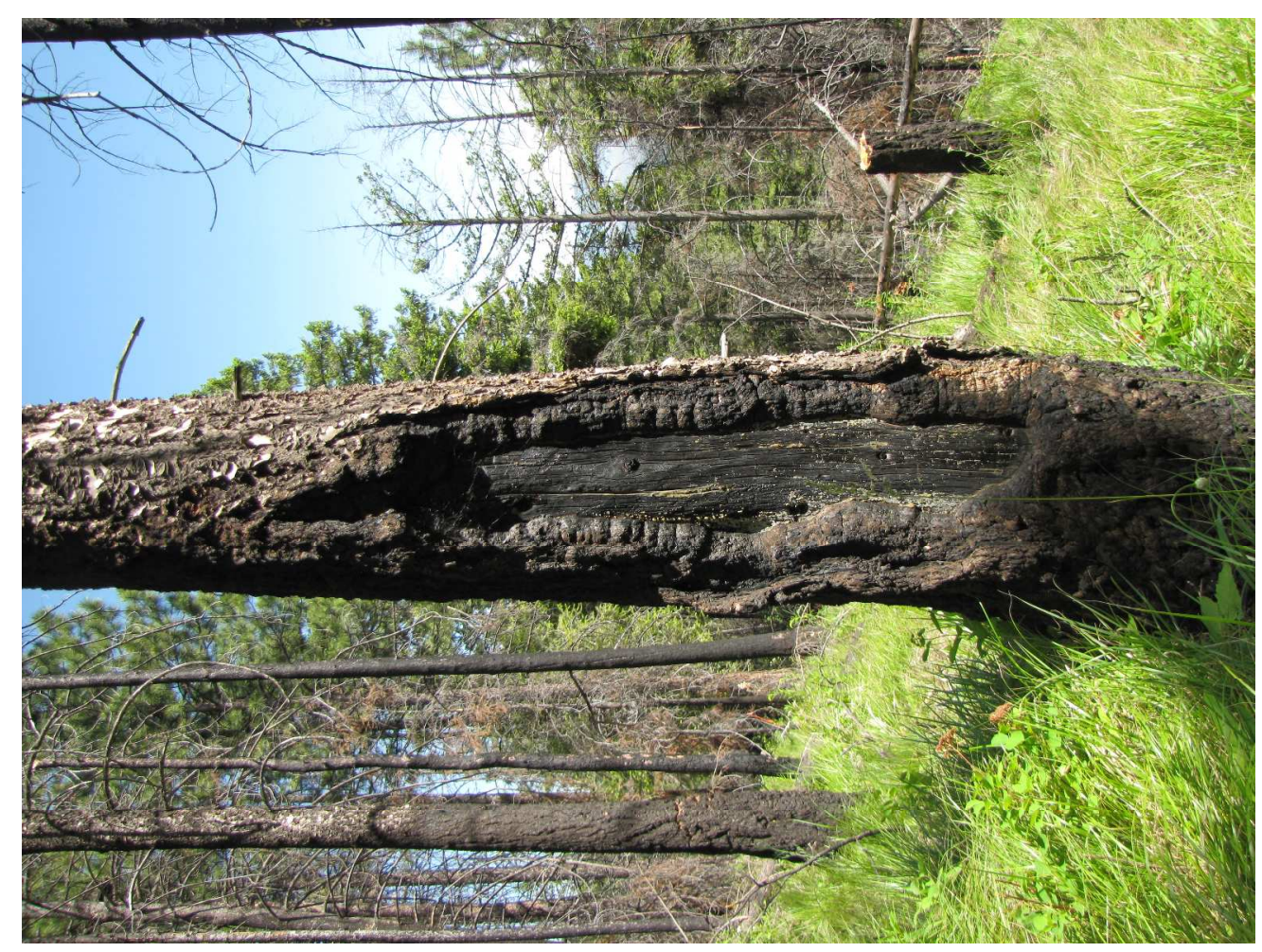

Figure 1. Open fire scar on ponderosa pine in 2011, injured in the Black Mountain fire of 2003 at the study area in the Lolo National Forest of western Montana, USA. $514 \times 386 \mathrm{~mm}(180 \times 180 \mathrm{DPI})$ 


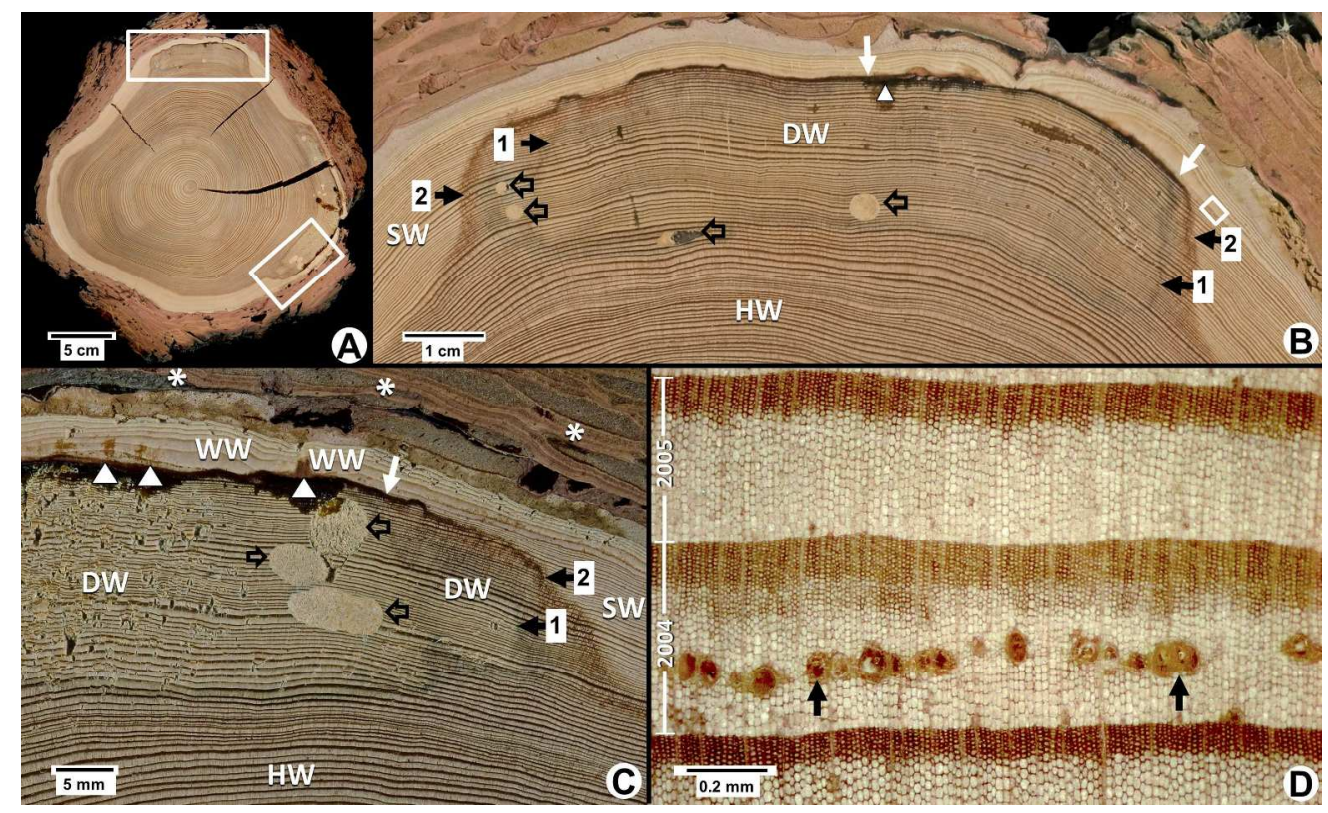

Figure 2. Transverse stem section of western larch containing (A) closed (upper) and open (lower) fire scars and two detail areas (white boxes). (B) Detail from A (upper) with discolored wood (DW), an arc of necrotic vascular cambium (white arrows), heartwood (HW), sapwood (SW), reaction zones (numbered black arrows), resin soaking (triangle), beetle bore holes (open arrows), and detail area (white box). (C) Detail from A (lower right) with woundwood (ww) closing the necrotic wound face beneath killed, adhering bark (white stars). (D) Detail from B with a tangential row of resin ducts (arrows) in latewood formed the year after fire injury. In the image, the 2003 ring is located beneath the 2004 ring and cropped.

$1162 \times 707 \mathrm{~mm}(61 \times 61 \mathrm{DPI})$ 


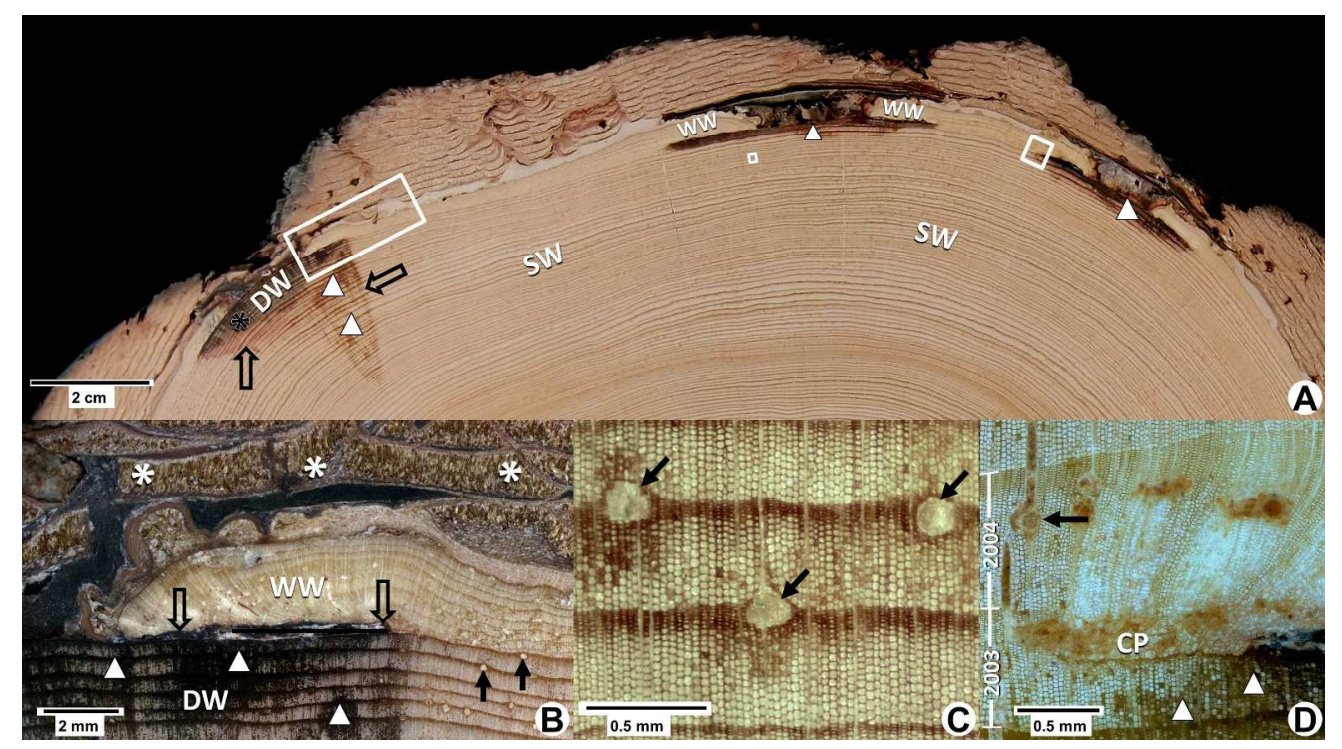

Figure 3. Transverse stem section through three fire scars of ponderosa pine containing (A) woundwood $(W W)$, discolored wood (DW), reaction zones (open arrows), resin soaking (triangles) and three detail areas (white boxes). (B) Detail from A (left) with WW covering a remnant of killed phloem (open arrows) retained on the wound surface and killed, adhering bark (white stars). (C) Detail from A (center) with constitutive resin canals in latewood (arrows). (D) Detail from $A$ (right) with a callus pad (CP) and traumatic resin ducts (black arrow).

$1200 \times 669 \mathrm{~mm}(61 \times 61 \mathrm{DPI})$ 


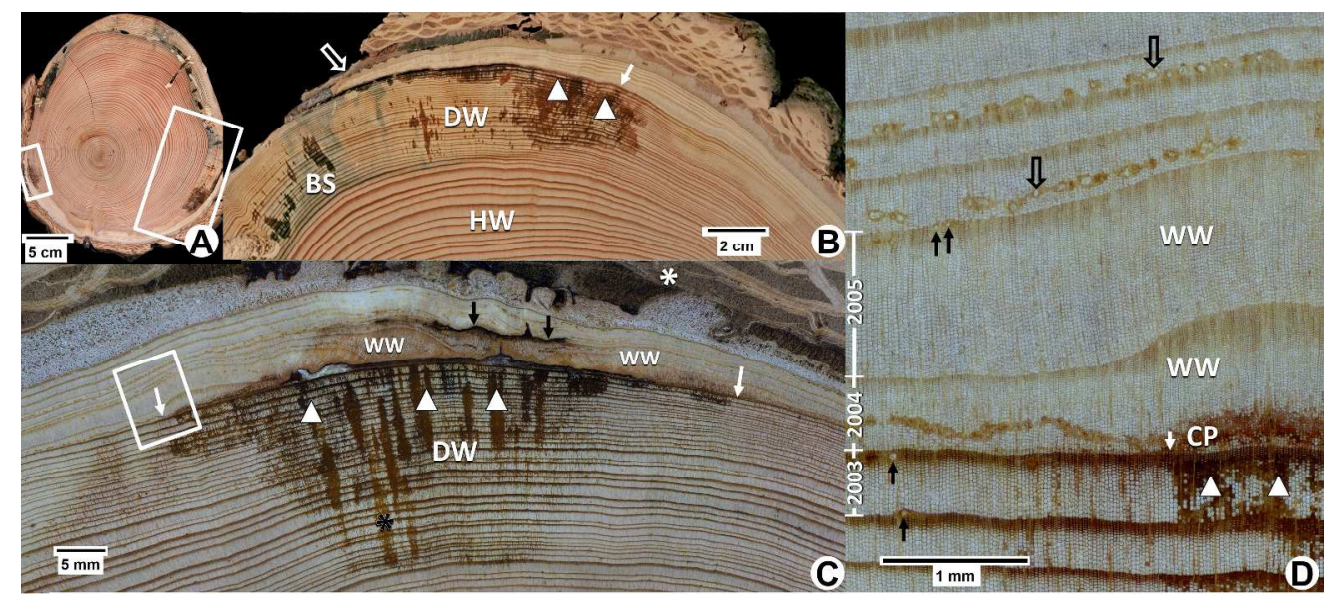

Figure 4. Transverse stem section of Douglas-fir containing (A) a large open (upper half of section), a closed fire scar (lower left), and two detail areas (white boxes). (B) Detail from A (right) with extensive discolored wood (DW), bluestain (BS), heartwood (HW), resin soaking (triangles), the edge of the necrotic vascular cambium (white arrow) and thin bark and narrow phloem (open arrow). (C) Detail from A (left) with the arc of necrotic cambium (between the white arrows), woundwood (WW) and necrotic cambium associated with a later injury (black arrows), and a detail area (white box). (D) Detail from $C$ with isolated constitutive resin ducts (black arrows), a callus pad (CP), radially-flattened tracheids and successive tangential rows of traumatic resin ducts occur in the 2006 and 2008 growth rings (open black arrows).

$1219 \times 545 \mathrm{~mm}(96 \times 96$ DPI) 


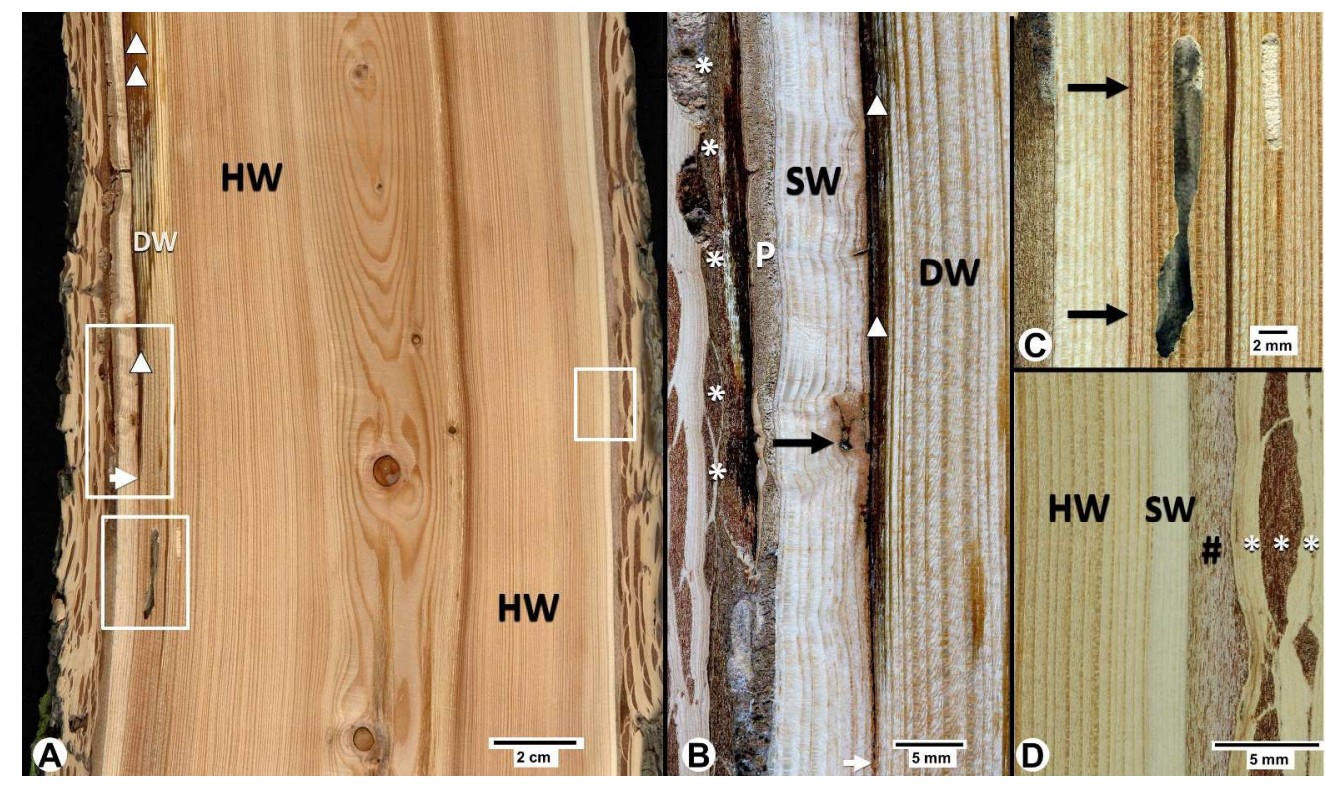

Figure 5. Longitudinal stem section through a fire scar of Douglas-fir. (A) Resin soaking (triangles) above the lower limit of killed vascular cambium (white arrow), discolored wood (DW), and heartwood (HW), and three detail areas (white boxes). (B) Detail from A (center left) with adhering killed bark (stars) located to the outside of new phloem and thin periderm (collectively labelled P). Sapwood (SW) frequently contained wavy grain and occasional inclusions (arrow). (C) Detail from A (lower left), with a barrier zone (arrows) and beetle bore holes in DW. (D) Detail from the uninjured face of A (right), showing the narrow band of healthy SW to the outside of heartwood $(\mathrm{HW})$ as well as thick phloem (\#), and the well-developed outer bark (white stars).

$1228 \times 720 \mathrm{~mm}(61 \times 61 \mathrm{DPI})$ 